\title{
A REVIEW OF ENTREPRENEURSHIP EDUCATION IN TEACHER EDUCATION
}

\author{
${ }^{1}$ İsa Deveci \& ${ }^{2}$ Jaana Seikkula-Leino \\ ${ }^{1}$ Faculty of Education, Kahramanmaras Sutcu Imam University \\ Kahramanmaras, Turkey \\ ${ }^{2}$ Faculty of Education, Teacher Training School Turku, Turku \\ University, Finland
}

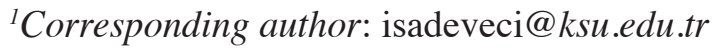

Received: 28 August 2017

Accepted: 1 January 2018

\begin{abstract}
Purpose - The aim of this study is to examine studies conducted on entrepreneurship education in teacher education.

Methodology - A thematic analysis was used in this study that outlines the similarities and differences in the studies conducted on entrepreneurship education in teacher education.

Findings - The purpose of the studies in question is mostly to discuss curriculum, teacher training, economy and unemployment, entrepreneurial characteristics and the importance of teachers. The studies mostly aim to examine the attitudes, perceptions and views of students, teachers or other educators regarding entrepreneurship education. There are a lot of study results highlighting the importance of entrepreneurship in teacher training. The biggest emphasis is laid upon methods, techniques, models or strategies used in entrepreneurship education. The recommendations put forward in the studies reviewed mostly concern a basic level of education. Many of these studies state that in-service training should be given to teachers at the basic education level with regard to entrepreneurship education.
\end{abstract}

Significance - This study can contribute to the literature in three different ways. Firstly, by presenting the current status of the studies on entrepreneurship education as a contemporary subject in 
teacher education. Secondly, it will shed light on the studies that will be conducted in the future as to how to approach the subject of entrepreneurship education in teacher education. Thirdly, by investigating studies that draw attention to entrepreneurshipeducation in teacher education, so as to provide a better understanding of the importance of entrepreneurship education.

Keywords: Teacher education, entrepreneurship, entrepreneurship education, thematic review.

\section{INTRODUCTION}

In recent years, many countries have come up against problems of unemployment and many have plunged into a misson of creating new business opportunities for their citizens. Unemployment has compelled countries to find ways to enable their citizens to become self-employed. Under these circumstances, the concepts of entrepreneurship and entrepreneurship education are now appearing in educational curriculums in many countries. As such, it is seen as a basis for developing social and economic well-being in the European Union (EU). Therefore, to a large extent, the contribution of entrepreneurship and entrepreneurship education at the EU level is emphasized (European Commission, 2006; European Commission, 2010). Entrepreneurship is viewed as an important factor with regard to economic growth in a national economy (Minniti \& Lévesque, 2010; Zalan \& Lewis, 2010). In this regard, employers want their employees to possess entrepreneurial characteristics (Ali, Lim, Ismail, Abdul Rahim, Isa, \& Ismail, 2014). It can, therefore, be said that in many developed and developing countries where national and international projects have been organised, students should be encouraged to practice business reports and attend practical business meetings so that, from an early age, they are acquainted with the concept of entrepreneurship. It has been observed that the connection between education and entrepreneurship has become very significant in recent years (Mars \& Rios-Aguilar, 2010).

As a concept, entrepreneurship is defined as the individual ability to find a business idea and transform it into practice (European Commission, 2011). Schumpeter (1934) states that innovation 
is the main process for entrepreneurship. This means increasing productivity, and performing a realignment of resources to produce new products or new methods. Furthermore, Knight (1921) argues that entrepreneurship is the process of uncertainty. So it can be said that the entrepreneur tries to strike a balance in markets. Bygrave and Hofer (1991) argue that entrepreneurs are people who perceive an opportunity and create an organization by following it. In this sense, entrepreneurship is defined as the study of opportunity sources that consist of processes in which opportunities are discovered, evaluated and used (Shane \& Venkataraman, 2000). As we may see, the concept of entrepreneurship should not just be considered as the process of creating jobs, as it should take into account the effect on individual behaviour of different activities related to jobs (Kuratko $\&$ Hodgetts, 2004). From this point of view, it can be said that there needs to be an education process for entrepreneurship and it is at this point that the concept of entrepreneurship education comes to mind.

The study of entrepreneurship education is based, in large measure, on a conceptual understanding of entrepreneurship and learning. Entrepreneurship education is concerned with learning for entrepreneurship, learning through entrepreneurship, and learning about entrepreneurship (Gibb, 2005). For this reason, it is stated that entrepreneurship education should be considered both as a learning method and as a learning content (Remes, 2003). Moreover, entrepreneurship education has been defined as a research focused process enabling us to investigate the most favorable education process to produce graduates in order to transform them into individuals who have life skills (Abiogu, 2011). Furthermore, entrepreneurship is also referred to as problem solving process (Amos \& Onifade, 2013). Additionally, entrepreneurship education is seen as a transfer of ideas; it has, in fact, been described as the transfer of learned knowledge and skills to new situations (Amos \& Onifade, 2013; Gustafsson-Pesonen \& Remes, 2012). Entrepreneurship education is based on two different approaches. The first approach is about creating a company or job. The education provided with this approach includes management subjects as well as subjects related to establishing a new company or business. The second approach focuses on the individual and aims to improve the entrepreneurial attitudes and behaviours of the students (European Commission, 2004). In this sense, the second approach in education 
is emphasised. So, it is seen that the development of students' creativity and innovation has gained importance in the training given in the field of education (Abiogu, 2011). Moreover, entrepreneurship education is aimed at improving the entrepreneurial mindset that is defined as rapid perception by transforming behaviour into action under ambiguous conditions (Ireland, Hitt, \& Sirmon, 2003).

It can be said that, until recently, entrepreneurship education has not become widespread in the general context of education (Haara \& Jenssen, 2016). However, the increasing importance of entrepreneurship in the education sector is becoming widespread (Haara \& Jenssen, 2016). One of the priority efforts in the EU has been to develop entrepreneurship education in teacher education (GHK, 2011). Moreover, from the EU perspective, teacher education is not, as yet, fully incorporated into most national strategies and does not form part of teachers' continuing professional development (European Training Foundation, 2010). In this sense, entrepreneurship is included in European Commission Reports as a priority area at all levels of teacher education (European Commission, 2011, 2013). In primary and secondary teacher education in particular, there are no courses that will improve information and skills to pre-service teachers about entrepreneurship and innovation; it is merely recommended that trainee teachers learn about subjects regarding entrepreneurship and innovation (Kleppe, 2002). On the other hand, many countries are facing a shrinking global job market with economic indicators showing that this will increase the problems faced by students in the future. Therefore, it can be said that students need to be ready for such difficulties encountered in their later life. Consequently, it is recommended that such preparation should primarily start from the teacher education curriculum (Correia, Wang, \& Baran, 2010).

It is widespread knowledge that entrepreneurship education in pre-service teacher training is either absent or insufficient in many countries. Moreover, attention should be drawn to the fact that, with regardtoentrepreneurshipeducation, in-serviceteachersarefrequently unprepared in terms of both theoretical knowledge and in-classroom experience. For example, teachers' attitudes have been shown to be one of the biggest barriers to the practice of entrepreneurship education and the successful teaching of entrepreneurship (Gustafsson-Pesonen \& Remes, 2012). At this juncture, it can be said that the biased approach of unprepared teachers with regard 
to entrepreneurship education practice in classrooms has adversely affected its classroom application. As a matter of fact, Kbathgate, Mostert, and Sandland (2013) state that teachers should step up to the plate in order to improve the entrepreneurial characteristics of students. In a similar manner, Silva (2013) indicates, that teachers should understand the meaning of the concept of entrepreneurship and how it should be practiced. Unfortunately, it is pointed out that few teachers have information and experience of the educational infrastructure require for entrepreneurship education (Fagan, 2006). Moreover, it has been seen that teachers need to have experience and knowledge regarding entrepreneurship education in order to teach to their students through experimental methods (GustafssonPesonen \& Remes, 2012). In this sense, it can be said that the studies conducted regarding entrepreneurship education in teacher training are very important in informing teachers and educators about entrepreneurship education.

In relation to the literature on entrepreneurship education, we have found studies on all almost every level of education. For instance, Konokman and Yelken (2014) investigate entrepreneurial levels of pre-service teachers regarding pre-school education. Some researchers examine opinions of primary school teachers regarding entrepreneurship education (Akyürek \& Şahin, 2013; Lepistö \& Ronkko, 2013). Other researchers probe the views of middle school teachers about how entrepreneurship is to be included in the process of education (Seikkula-Leino, Ruskovaara, Ikavalko, Mattila, \& Rytkola, 2010). Moreover, it was also found in the literature that entrepreneurship education curriculums have already been prepared and practiced amongst middle school and high school teachers (Gardner,2013).Van Dam, Schipper, and Runhaar(2010) examine the qualifications underlying the entrepreneurial teaching in vocational schools as well as at high school level. On the other hand, Chukwurah (2010) examines the opinions of vocational and technical teacher trainers in order to examine the effect of entrepreneurship education on teacher education at university level. In addition, Seikkula-Leino, Ruskovaara, Hannula and Saarivirta (2012) investigate the activities involved in entrepreneurship education executed by teacher educators who work in university applied sciences, teacher training schools and vocational schools. Looking at the literature in the teaching field, some studies examine the opinions of science teachers in middle schools (Bacanak, 2013; Bolaji, 2012; Hsiao, 2010; Koehler, 2013). The aim of Hietanen's study (2013) is to interpret and investigate 
entrepreneurial activities conducted by primary school pre-service teachers in music courses at university level. In addition, Gardner's project (2013) provides education on entrepreneurship to a teacher group composed of middle school math teachers, and Orji (2014) researches the perceptions of math teachers about entrepreneurship. Moreover, there are studies related to curriculum or instructional technology teachers (Gardner, 2013; Orji, 2014), trade teachers (Bakar, Pihie, Akmaliah, Konting, \& Angking, 2001; Fischer, 2000; Gardner, 2013; Orji, 2014), and economics teachers and economic management science teachers (Gardner, 2013; Pistorius, 2011). It is also possible to reference compilation and theoretical studies in the literature, seeing as entrepreneurship education is an up-to-date subject in education. For example, some of the studies focusing on science education demonstrate a better understanding of the manner of application and importance of entrepreneurship education (Adeyemo, 2009; Ezeudu, Ofoegbu, \& Anyaegbunnam, 2013). One study also provides theoretical knowledge and a better understanding of entrepreneurship education in music education at university level (Snow, 2012). Moreover, another study reflects some important dimensions and the problems of entrepreneurship education (Caseiro \& Alberto, 2013), and another explains the role of school directors in the development of entrepreneurship education (Ememe, Ezeh, \& Ekemezie, 2013). Borase (2014) reveals the definition and characteristics of entrepreneurial teachers. Finally, a different study suggests a model for entrepreneurship education (Kbathgate et al., 2013).

Emphasis on entrepreneurship education has increased in compulsory education at both national and international levels (European Commission, 2011; The Ministry of Education, 2017). The compulsory education situation directly affects in-service teacher training (Haara \& Jenssen, 2016). Pre-service teacher training also plays an important role in creating change in the future (Borasi \& Finnegan, 2010). In this sense, the entrepreneurship concept, as it appears in the field of education, is reflected primarily in teacher education. As can be seen in the relevant literature, very different results (positive and negative) have been obtained in studies that have been carried out. But the general trend in study outcomes is not fully predictable. This situation forced us to discover the results of studies conducted on entrepreneurship education in teacher training in general.

We also wondered whether the concept of entrepreneurship for 
teacher education is a temporary fashion, or whether it is a topic that will survive in the long-term. We decided to extensively investigate the studies carried out on this subject in order to answer this question. For example, the needs specified and the results achieved in the studies conducted will give us an idea of why this concept is important. Suggestions also put forward in the studies conducted will also draw attention to the importance of entrepreneurship education in terms of teacher training. In this way, the significance of entrepreneurship education in teacher training will become clearer. Therefore, many studies have recently been conducted to be added to the body of literature, and one can depend on their being up-todate on the subject of entrepreneurship education. However, the literature does not yet feature studies of entrepreneurship education as current subjects in teacher education in terms of general features (year, number of authors, publication type) and content properties (justification, objectives, methods, data collection tools, sample, conclusions and recommendations). Therefore, it is thought that this study can contribute to the literature in three different ways. Firstly, by presenting the current status of the studies conducted about entrepreneurship education as a contemporary subject in teacher education, and secondly, by shedding light on the studies that will be conducted in the future about how to handle entrepreneurship education in teacher education. Thirdly, by investigating studies that draw attention to entrepreneurship education in teacher education, so as to provide a better understanding of the importance of entrepreneurship education.

The aim of this research is to examine the studies conducted on entrepreneurship education in teacher education in terms of general features (year, authors, publication type) and content properties (needs, aims, methods, data collection tools, sample, results and recommendations). For this purpose, the study questions are as follows:

- What are the general features of the study (number of authors, publication year, and publication type)?

- What are the needs underlying the background of the study?

- What are the main aims put forward in the study?

- What are the methods considered in the study, the data 
collection tools and the type of sample?

- What are the main conclusions reached in the study?

- What kinds of recommendations for further research are made in the study?

\section{METHODOLOGY}

This study is a literature review. A literature review allows researchers to see other study results on the subject under consideration (Fraenkel \& Wallen, 2006). We primarily gathered scientific publications in order to undertake the literature review. We identified 76 scientific publications in the form of academic theses, articles and conference papers. Thematic analysis was used in this research in order to outline the similarities and differences in the studies conducted on entrepreneurship education in teacher education. These studies were examined through the use of a matrix previously used by other studies (Çalık, Ayas, \& Ebenezer, 2005; Kurnaz \& Çalik, 2009; Ünal, Çalik, Ayas, \& Coll, 2006). These 76 studies examined the following features through the matrix; general features (year, number of authors, publication type); and content features [justification, objectives, methods (design, sample type, data collection instruments), conclusions and recommendations]. Studies investigated in the bibliography section have been marked with “*”. They were then summarised according to their similarities and differences. Each individual publication was identified separately using this matrix (Table 1).

\section{Table 1}

The Matrix Used in Determination of Entrepreneurship Education Conducted in Teacher Education

\begin{tabular}{lll}
\hline Themes & Codes & Explanations \\
\hline $\begin{array}{l}\text { General } \\
\text { features }\end{array}$ & $\begin{array}{l}\text { Number of } \\
\text { authors }\end{array}$ & Publication year of the study \\
& Publication type & $\begin{array}{l}\text { Publication group (Article, Proposal, Thesis } \\
\text { etc.) }\end{array}$ \\
\hline
\end{tabular}




\begin{tabular}{|c|c|c|}
\hline Themes & Codes & Explanations \\
\hline \multirow{7}{*}{$\begin{array}{l}\text { Content } \\
\text { features }\end{array}$} & Need & Reason for the study \\
\hline & Aim & Purpose of study \\
\hline & Method & $\begin{array}{l}\text { Qualitative (case study, phenomenological } \\
\text { research, etc.), Quantitative (survey, } \\
\text { experimental, etc.) }\end{array}$ \\
\hline & $\begin{array}{l}\text { Data collection } \\
\text { tools }\end{array}$ & $\begin{array}{l}\text { Tools used to obtain data (observation, } \\
\text { interview, Likert scale, etc.) }\end{array}$ \\
\hline & Sample & $\begin{array}{l}\text { Which field/course (science, music) and } \\
\text { which level (elementary, secondary, etc.) }\end{array}$ \\
\hline & Results & Basic results of the studies \\
\hline & Recommendation & Basic implementations of studies \\
\hline
\end{tabular}

To find studies conducted on entrepreneurship in teacher education, with the objective of more specific searching, some specific words were entered into search engines such as 'primary school' or 'secondary school', and 'entrepreneurship education', 'entrepreneurship', 'entrepreneur', 'initiative', 'teacher' or 'teacher training'. Since research into business and economics was consistently found when the search was conducted with 'keywords' or a 'summary' entered into the search engines, the settings enabled searches to be possible using titles. In addition, studies were placed in an order of 2000 after databases were taken into account. When scanning was performed according to the above keywords, the oldest article that came out was from 2000. Therefore, the year 2000 was taken into account. The articles, papers and theses to be examined were decided upon according to the above key words. Unpublished studies were not taken into consideration. Databases used during source scanning process can be summarised as follows: Google Scholar, PROQUEST Dissertations and Theses Full Text, Emerald Journals and Theses Database, Nordic Base of Early Childhood Education and Care, Teacher References Center, the Education Resources Information Centre (ERIC), PsycArticles (ProQuest), Academic Search Premier (EBSCO), Science Direct, Web of Science, Social Science Citation Index, Education Research Complete, SocINDEX With Full Text, Bibliography of Asian Studies, MathEduc, JSTOR, Taylor \& Francis Online Journals, Wiley Online Library, and the 
Thesis Center of Council of Higher Education. The studies were selected according to certain criteria; the selected work consisted of published articles, conference papers presented at scientific meetings, and completed master's and doctoral dissertations. The limitations, then, consisted of a lack of access to research that went beyond the scanning criteria of the research, or studies that were inaccessible because they were cited in databases not used in this study. It was not possible to access all the articles and theses at a national level in the databases mentioned here. Thus, studies conducted at the national level, except for the databases mentioned here, were limited to the use of Google Scholar.

The search benefitted from the descriptive statistics and content analysis in the analysis process of the publications found through databases. An attempt was made to facilitate the interpretation of data by creating codes and themes during the content analysis process. The data should be carefully reduced and coded step-bystep during the theme-making process (Given, 2008). Therefore, firstly, publications obtained as a result of the literature search were reviewed. Secondly, publications were individually summarised according to the criteria included in the matrix (See Table 1). Thirdly, codes were created. Fourthly, a code that evokes similar results or sense was brought together after the encoding processes under a theme. Fifthly, each theme was named and coding processes were finalised depending on the codes used to facilitate interpretation of the data in this manner. In case of any uncertainity during the coding process, we tried to reconsider the studies and assure the truthfulness of the meaning inferred from the study in order to ensure internal validity. The encoding process of all the studies was performed in this manner. Finally, the study data was re-coded by a second expert researcher, seeing as the prejudices and personal thoughts of the researcher can have a negative effect on the reliability of a study during the coding process. In this way, for the randomly selected "aim" category, inter-observer consistency was found to be $84 \%$ (see Table 2). After the coding was done, conflicting codes (12 codes) were determined and we opted for the codes that the two researchers agreed upon. Moreover, a different researcher examined the codes, rather than research authors, in order to ensure the work of the existing researchers was accurate and fair in terms of ethics. 
Table 2

Publications are Coded by Author and a Different Researcher in Terms of Aims

\begin{tabular}{|c|c|c|c|c|c|c|c|}
\hline 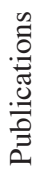 & 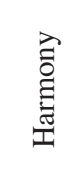 & 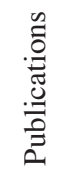 & 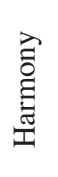 & 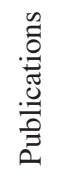 & 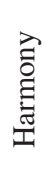 & 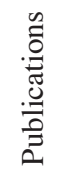 & 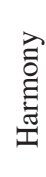 \\
\hline 1 & $\mathrm{~A}^{*}$ & 21 & A & 41 & B & 61 & A \\
\hline 2 & A & 22 & B & 42 & A & 62 & B \\
\hline 3 & A & 23 & A & 43 & A & 63 & A \\
\hline 4 & A & 24 & A & 44 & A & 64 & A \\
\hline 5 & A & 25 & A & 45 & B & 65 & A \\
\hline 6 & A & 26 & A & 46 & A & 66 & A \\
\hline 7 & A & 27 & B & 47 & A & 67 & A \\
\hline 8 & A & 28 & A & 48 & A & 68 & A \\
\hline 9 & $\mathrm{~B} * *$ & 29 & $\mathrm{~A}$ & 49 & $\mathrm{~A}$ & 69 & A \\
\hline 10 & B & 30 & B & 50 & $\mathrm{~A}$ & 70 & B \\
\hline 11 & A & 31 & A & 51 & A & 71 & A \\
\hline 12 & A & 32 & B & 52 & A & 72 & A \\
\hline 13 & A & 33 & A & 53 & A & 73 & A \\
\hline 14 & A & 34 & A & 54 & A & 74 & A \\
\hline 15 & A & 35 & A & 55 & A & 75 & A \\
\hline 16 & A & 36 & A & 56 & A & 76 & A \\
\hline 17 & A & 37 & B & 57 & $\mathrm{~A}$ & & \\
\hline 18 & B & 38 & A & 58 & A & & \\
\hline 19 & A & 39 & A & 59 & A & & \\
\hline 20 & A & 40 & A & 60 & A & & \\
\hline
\end{tabular}

A*Similar opinion, $\mathrm{B} * *$ Different opinion

\section{FINDINGS}

Table 3 shows that most of the studies were conducted between 2009 and 2016 (Adeyemo, 2009; Deveci \& Seikkula-Leino, 2016; 
Dijk \& Mensch, 2015; Hannula, 2011; Heilbrunn, 2010; Lepistö \& Ronkko, 2013; Orji, 2014; Seikkula-Leino et al., 2012). Most of the studies had one or two authors (Çelik, 2010; Deveci, 2016a; Pan \& Akay, 2015; Rönkkö \& Lepistö, 2015) and most were carried out as an article (Ruskovaara \& Pihkala, 2015; Sipon, Pihie, Rahman, \& Manaf, 2015; Suryanti, 2013).

Table 3

General Information about the Studies

\begin{tabular}{ccc}
\hline Categories & Sub-categories & $\mathbf{f}^{*}$ \\
\hline & 2000 to 2002 & 4 \\
& 2003 to 2005 & 1 \\
Publication & 2006 to 2008 & 5 \\
years & 2009 to 2011 & 16 \\
& 2012 to 2014 & 30 \\
& 2015 to 2016 & 20 \\
The number of & 1 & 32 \\
authors & 2 & 22 \\
& 3 & 9 \\
Publication & 4 & 9 \\
type & 5 and more & 4 \\
& Article & 11 \\
\hline
\end{tabular}

*Frequency

The Distribution of the Studies in Terms of Needs

Studies examined in terms of need were collected under five themes: (1) curriculum, (2) teacher training, (3) economy/unemployment, (4) entrepreneurial characteristics, and (5) the importance of teachers.

Curriculum. The subjects of study were mostly on curricula (Bakar et al., 2001; Cheung, 2008; Hamid, 2013; Seikkula-Leino, 2011). The curricula concerned here were basic education curricula (Hamid, 2013; Kleppe, 2002; Orji, 2014); for example, coverage of 
entrepreneurship education in primary and/or middle school curricula (Hamid, 2013; Orji, 2014), lack of entrepreneurship education study at primary school level (Kleppe, 2002), inadequacy of the high school curriculum in terms of entrepreneurship education (Cheung, 2008), and the necessity of expanding entrepreneurship in general education and vocational education (Caseiro \& Alberto, 2013).

Teachertraining. The other subjectunderconsideration was generally teacher training (Lepistö \& Ronkko, 2013; Torokoff, 2006; Van Dam et al., 2010). Topics here included the situation of entrepreneurship in teacher training (Hannula, Ruskovaara, Seikkula-Leino, \& Tiikkala, 2012), the entrepreneurial characteristics of educators (Armstrong $\&$ Tomes, 2000), teachers' views about entrepreneurship education practices, teachers' attitudes towards entrepreneurship education (Gustafsson-Pesonen \& Remes, 2012), and the lack of knowledge and experience in entrepreneurship education.

Economy/unemployment. Some of the other subjects for study were the deterioration of national economies and increases in unemployment rates, the necessity for young individuals to have entrepreneurial characteristics and, finally, the need for teachers to play an important role in entrepreneurship education (Amos \& Onifade, 2013; Bolaji, 2012; Pistorius, 2011; Seikkula-Leino et al., 2010). This included high unemployment rates in the country (Amos \& Onifade, 2013; Ememe et al., 2013; Nwoye, 2012), and the large number of general or technical education faculty graduates who are unemployed (Chou et al., 2011; Suryanti, 2013).

Entrepreneurial characteristics. Some studies have pointed out that individuals lack entrepreneurial characteristics (Baranović \& Stibric, 2007; Correia et al., 2010; Suryanti, 2013). For example, individuals' lack of characteristics such as self-employment and setting up a new business (Ezeudu et al., 2013; Pihie et al., 2011b; Pistorius, 2011), the necessity of providing young individuals with entrepreneurial characteristics to achieve economic growth (Bolaji, 2012), and the EU's aim to provide students with entrepreneurial characteristics (Baranović \& Stibric, 2007).

The importance of teachers. It is stated that teachers play a very important role in providing students with entrepreneurial 
characteristics (Akyürek \& Şahin, 2013; Gardner, 2013; Hannula, 2011). Examples include the important role played by primary school teachers in entrepreneurship education (Akyürek \& Şahin, 2013), and teachers as an important factor in introducing entrepreneurial characteristics (Hannula, 2011).

\section{The Distribution of the Studies in Terms of Aims}

The studies investigated according to the aims were collected under eight themes: : (1) attitudes, perceptions, or views, (2) coverage in science curriculum, (3) entrepreneurial activities, (4) better understanding, (5) coverage in the general curriculum, (6) the role of principals, (7) developing an education program/module/model, (8) factors influential on behaviours.

Attitudes, perceptions, or views. When the studies were investigated with regard to aims, it was noticed that the studies were mostly carried out to determine views, perceptions and attitudes (Armstrong \& Tomes, 2000; Çelik, Gürpınar, Başer, \& Erdoğan, 2015; Pihie et al., 2011a, 2011b; Torokoff, 2006). The studies under this theme mostly aimed to designate the views of pre-service teachers, teachers and educators about entrepreneurship, entrepreneurship education and entrepreneurial characteristics (Akyürek \& Şahin, 2013; Arpac1, 2015; Baranović \& Stibric, 2007; Deveci \& Seikkula-Leino, 2016; Mattila, Rytkölä, \& Ruskovaara, 2009).

Coverage in science curriculum. This theme was followed by objectives connected to science education (Bolaji, 2012; Çelik et al., 2015; Deveci, 2016a, 2016b; Deveci \& Seikkula-Leino, 2016). The studies under this theme were, therefore, conducted with aims such as the integration of entrepreneurship into the science curriculum, revealing the influence of science lessons on entrepreneurial characteristics, and creating other related activities (Buang, Halim, \& Meerah, 2009; Deveci, Zengin, \& Çepni, 2015; Ezeudu et al., 2013; Kleppe, 2002; Ugwu, La'ah, \& Olotu, 2013).

Entrepreneurial activities. This theme was followed by the consideration of aims about entrepreneurial activities that were designed, used and evaluated within the scope of entrepreneurship education (Hannula et al., 2012; Hietanen, 2013; Oplatka, 2014; Ruskovaara, Pihkala, Seikkula-Leino, \& Järvinen, 2015). For 
example, investigating the influences of entrepreneurial activities on teachers and students (Cheung, 2008), examining the ways entrepreneurship is taught in different middle schools (Brown, 2012), examining the entrepreneurial activities created by teachers (Oplatka, 2014), and showing practices that have a potential to encourage creativity, innovativeness and entrepreneurship (Cankar, Deutsch, Zupan, \& Cankar, 2013).

Better understanding. This theme included aims concerning better understanding of entrepreneurship education (Adeyemo, 2009; Caseiro \& Alberto, 2013; Seikkula-Leino, 2011; Seikkula-Leino et al., 2012), including making teachers knowledgeable about entrepreneurship education (Fagan, 2006), giving information about the problems and some important dimensions of entrepreneurship education (Caseiro \& Alberto, 2013) enabling entrepreneurship education to be understood better (Adeyemo, 2009), and explaining entrepreneurship with its various dimensions in teacher training (Žibènienè, 2012).

Coverage in the general curriculum. Aims to determine how entrepreneurship is included in the general curricula under this theme were included. For example, examining the ways in which entrepreneurship is integrated into teaching processes in primary school and middle school levels (Ruskovaara, Pihkala, Rytkölä, \& Seikkula-Leino, 2010), examining the coverage of entrepreneurship education in curricula and strategies of vocational teacher training units (Hannula, 2011), describing the way entrepreneurship is integrated into the partnership model (Seikkula-Leino, 2011).

The role of principals. In some studies, it was seen that the the role of principals was examined in terms of entrepreneurship education in educational institutions (Deakins, Glancey, Menter, \& Wyper, 2005; Hamid, 2013). For example, to determine the role of school principals in the improvement of entrepreneurship education in primary schools (Ememe et al., 2013) and the role of school principals in the process of developing entrepreneurship education in Scotland was examined (Deakins et al., 2005).

Developing an education program/module/model. The effect of the developed training programme, module or model on the students, teachers or educators was examined (Deveci, Zengin, \& Çepni, 2015; Gustafsson-Pesonen \& Remes, 2012; Kbathgate et al., 2013). For example, investigating the influence of entrepreneurial development 
coaching on teachers (Gustafsson-Pesonen \& Remes, 2012), investigating the effectiveness of the education program designed in exploring business lessons (Fischer, 2000), and developing an entrepreneurial learning model built upon a problem-based learning approach (Suryanti, 2013).

Factors influential on behaviours. Here, factors such as "selfefficacy" and "adopting entrepreneurship" factors, which are supposed to affect the interventional learning behaviours of technical and vocational teacher candidates in high school education with structural models of equality (Chou et al., 2011), were examined. Other investigations examined the competencies that underlie the entrepreneurial behaviour of teachers in vocational schools at high school level (Van Dam et al., 2010).

\section{The Distribution of the Studies in Terms of Methods}

As seen Table 4, the investigated studies were collected under three themes in terms of preferred method: (1) quantitative approach, (2) qualitative approach others, (3) others.

Table 4

The Distribution of the Methods Used in the Studies

\begin{tabular}{lcrc}
\hline Categories & Sub-categories & f & Total \\
\hline $\begin{array}{c}\text { Quantitative } \\
\text { approach }\end{array}$ & Survey & 25 & 29 \\
& Experimental study & 4 & \\
Qualitative & Phenomenological study & 12 & \\
approach & Case study & 6 & 23 \\
& Survey & 4 & \\
& Document analysis & 1 & \\
& Literature review/Theoretical study & 13 & \\
Other & Developing and implementing an & 6 & \\
& education module & 30 \\
& Longitudinal research & 3 & \\
& Proposal of an education model & 3 & \\
\hline
\end{tabular}

Quantitative approach. The survey method, which is under the 
theme of quantitative approach, was used most frequently in the studies (Akyürek \& Şahin, 2013; Amos \& Onifade, 2013; Bolaji, 2012; Orji, 2014; Pihie et al., 2011b; Pistorius, 2011). However, there were very few studies in which experimental design was employed (Bakar et al., 2001; Cankar et al., 2013; Fischer, 2000; GustafssonPesonen \& Remes, 2012; Heilbrunn, 2010), which is also under the theme of the quantitative approach.

Qualitative approach. It was seen that the phenomenological research method was preferred far more under the qualitative research theme (Armstrong \& Tomes, 2000; Cheung, 2008; Mattila et al., 2009; Oplatka, 2014; Peltonen, 2015). Some of the studies were designed as case studies (Brown, 2012; Buang et al., 2009; Hamid, 2013; Koehler, 2013). Document analysis was preferred in a few studies (Fakharzadeh, 2011).

Others. Employed methods were mostly literature reviews and theoretical research approaches that fall under the theme of 'other' (Adeyemo, 2009; Altan, 2015; Caseiro \& Alberto, 2013; Deveci \& Seikkula-Leino, 2015; Ezeudu et al., 2013; Fagan, 2006; Snow, 2012; Ugwu et al., 2013; Žibènienè, 2012). The theme of 'other' also included studies about developing an education program/education module, a longitudinal study and studies in which education models were proposed (Correia et al., 2010; Deakins et al., 2005; GustafssonPesonen \& Remes, 2012; Kleppe, 2002; Suryanti, 2013).

\section{The Distribution of the Studies in Terms of Data Collection Tools}

The data in Table 5 show that studies were collected under two themes according to the data collection tools used: (1) quantitative data collection tools, (2) qualitative data collection tools.

Table 5

The Distribution of the Data Collection Tools Used in the Studies 


\begin{tabular}{|c|c|c|}
\hline Categories & Sub-categories & $\mathrm{f}$ \\
\hline \multirow{4}{*}{$\begin{array}{l}\text { Quantitative } \\
\text { data collec- } \\
\text { tion tools }\end{array}$} & Likert-type scale & 32 \\
\hline & Online survey & 3 \\
\hline & $\begin{array}{l}\text { Short-answer questions (e.g., yes/no, I do/I } \\
\text { do not) }\end{array}$ & 3 \\
\hline & Multiple-question test & 2 \\
\hline \multirow{9}{*}{$\begin{array}{l}\text { Qualitative } \\
\text { data collec- } \\
\text { tion tools }\end{array}$} & & (continued) \\
\hline & Interview & 23 \\
\hline & $\begin{array}{c}\text { Relevant publications/literature review (e.g., } \\
\text { article, thesis, report) }\end{array}$ & 13 \\
\hline & $\begin{array}{l}\text { Questionnaire composed of open-ended } \\
\text { questions }\end{array}$ & 8 \\
\hline & $\begin{array}{c}\text { Documents (e.g., textbooks, workbooks, } \\
\text { archives) }\end{array}$ & 7 \\
\hline & $\begin{array}{c}\text { Participants' notes (e.g., texts, journals, } \\
\text { course plans) }\end{array}$ & 6 \\
\hline & Observation & 6 \\
\hline & Photos taken in the process & 1 \\
\hline & Field trips & 1 \\
\hline
\end{tabular}

Quantitative data collection tools. It was seen that likert-type scales were used the most among quantitative data collection tools (Amos \& Onifade, 2013; Chou et al., 2011; Chukwurah, 2010; Ejinkeonye \& Chukwuone, 2014; Deveci \& Çepni, 2015a, 2015b; Fischer, 2000; Gustafsson-Pesonen \& Remes, 2012; Hannula et al., 2012; Heilbrunn, 2010; Seikkula-Leino, 2011; Seikkula-Leino, Satuvuori, Ruskovaara, \& Hannula, 2015; Torokoff, 2006; Van Dam et al., 2010); some studies used online surveys (Cankar et al., 2013; Hannula et al., 2012; Ruskovaara \& Pihkala, 2013), multiple-question tests (Fischer, 2000; Nwoye, 2012), and short-answer questions (Hannula et al., 2012; Seikkula-Leino, 2011).

Qualitative data collection tools. In the investigated studies, the most common qualitative data collection tool was the interview (Armstrong \& Tomes, 2000; Brown, 2012; Cheung, 2008; Figueiredo-Nery \& Figueiredo, 2008; Gustafsson-Pesonen \& Remes, 2012; Hamid, 2013; Kleppe, 2002; Mattila et al., 2009; Oplatka, 2014; Suryanti, 2013). It was possible to find studies using relevant publications 
such as articles, theses and reports (Adeyemo, 2009; Borase, 2014; Caseiro \& Alberto, 2013; Ememe et al., 2013; Ezeudu et al., 2013; Hannula, 2011; Seikkula-Leino et al., 2012; Snow; 2012; Ugwu et al., 2013; Žibėnienè, 2012), questionnaires composed of open-ended questions (Baranović \& Stibric, 2007; Brown, 2012; GustafssonPesonen \& Remes, 2012; Orji, 2014; Torokoff, 2006), documents such as textbooks, workbooks and archives (Fakharzadeh, 2011; Hannula, 2011; Koçak, Polat, Çermik, Meral, \& Boztaş, 2015; Snow, 2012; Žibėnienè, 2012), participants' notes such as texts, journals and course plans (Gustafsson-Pesonen \& Remes, 2012; Hietanen, 2013; Koehler, 2013; Lepistö \& Ronkko, 2013), photos taken in the process (Koehler, 2013), and field trips (Gardner, 2013).

\section{The Distribution of the Studies in Terms of Sample}

As shown in Tables 6 and 7, the preferred sample groups in the studies were collected under two themes: (1) educators (teachers/ pre-service teachers), and (2) non-educational staff.

Table 6

Educational Staff Sample in the Studies

Categories

Sub-categories

111




\begin{tabular}{ccccccc}
\hline & General education & 1 & 13 & 9 & 2 & 9 \\
& Science education & - & - & 9 & 3 & 5 \\
& Vocational and technical education & - & - & 1 & 7 & 6 \\
& Trade and/or business exploring education & - & - & 4 & 2 & - \\
$\begin{array}{c}\text { Educator } \\
\text { staff } \\
\text { teachers/ } \\
\text { pre-service } \\
\text { teachers) }\end{array}$ & Economics education & - & 1 & 2 & 3 & - \\
& Mathematics education & - & - & 3 & 1 & - \\
& Handicraft and/or theater education & - & 1 & - & - & 1 \\
& Music education & - & - & - & 1 & 1 \\
& Pre-school education & - & - & - & - & 1 \\
& School principal & - & 3 & 5 & 1 & 1 \\
\hline
\end{tabular}

Educator staff. Sample groups were mostly chosen from general education rather than a specific teaching domain/branch. It was seen that primary and middle school levels were the most preferred in general education (Akyürek \& Şahin, 2013; Ay \& Acar, 2016; Brown, 2012; Dijk \& Mensch, 2015; Heilbrunn, 2010; Mattila et al., 2009; Oplatka, 2014). It was also seen that some of the studies were carried out with school managers (Deakins et al., 2005; Dijk \& Mensch, 2015; Hamid, 2013; Seikkula-Leino, 2011).

As for the sample groups chosen from specific branches, the studies were mostly conducted on sample groups from science education (Adeyemo, 2009; Armstrong \& Tomes, 2000; Bacanak, 2013; Deveci \& Seikkula-Leino, 2016; Kleppe, 2002; Nwoye, 2012; Ugwu et al., 2013). Another branch from which sample groups were included is vocational and technical education (Chou et al., 2011; Chukwurah, 2010; Mattila et al., 2009; Van Dam et al., 2010). Sample groups were also taken from trade/business exploring education and economic education (Bakar et al., 2001; Cheung, 2008; Fischer, 2000; Gardner, 2013; Orji, 2014). Other branches providing sample groups for study were mathematics, instructional technologies, handicraft and theatre, music education, expert teachers, pre-school, domestic science, agronomics, industrial arts, life skills and literature education (Amos \& Onifade, 2013; Bakar et al., 2001; Gardner, 2013; Hamid, 2013; Hietanen, 2013; Kleppe, 2002; Konokman \& Yelken, 2014; Lepistö \& Ronkko, 2013; Orji, 2014; Snow, 2012). In Table 7, preferred sample groups, with the exception of educator 
personnel, are given.

Table 7

Non-Educational Staff Sample in the Studies

\begin{tabular}{ccc}
\hline Categories & Sub-categories & $\mathrm{f}$ \\
\hline & Officers from different sectors & 2 \\
& Entrepreneurship activities/School environment & 2 \\
$\begin{array}{c}\text { Non-educa- } \\
\text { tional staff }\end{array}$ & Entrepreneurs & 1 \\
& Parents & 1 \\
& Municipal officials and empoloyees & 1 \\
& Employer & 1 \\
\hline
\end{tabular}

Non-Educational Staff. Additionally, entrepreneurs in the free market (Cankar et al., 2013), officers from different sectors (Hamid, 2013; Seikkula-Leino, 2011), and educational officials working in municipalities, as well as business owners and commercial and industrial officials (Seikkula-Leino, 2011), were also taken as sample groups.

\section{The Distribution of the Studies in Terms of Research Results}

The results found by the authors in the investigated studies were collected under seven themes: (1) methods/techniques/models and strategies, (2) deficiencies, (3)entrepreneurial characteristics/ competences/skills, (4) pertaining to science education, (5)the entrepreneurship education curriculum, (6) different variables, (7) positive indicators.

Methods/techniques/models and strategies. Most of the study results were under the theme of methods, techniques, models and strategies. For example, school administrators played an important role in entrepreneurship education practices (Deakins et al., 2005; Ememe et al., 2013), Teachers mostly used learning diaries and workplace visits in the learning process (Ruskovaara et al., 2010; Seikkula-Leino, 2011). Teachers mostly used problem-based active learning approaches, group work, stories and discussion methods, and extracurricular activities (Baranović \& Stibric, 2007; Ruskovaara 
et al., 2010; Seikkula-Leino, 2011). Also, teachers prefered teaching entrepreneurship as a cross-curricular theme (Baranović \& Stibric, 2007). In entrepreneurship education, teachers acted as a 'facilitating' teacher (Borase, 2014). Moreover for entrepreneurship education, teachers were satisfied with the methods, techniques or activities they use (Pistorius, 2011).

Deficiencies. There were a number of studies that have come to the conclusion that there are shortcomings and difficulties in entrepreneurship education. For example, in entrepreneurship education, there was an inconsistency/conflict between aims and practices (Seikkula-Leino et al., 2010); teachers did not know how to implement activities properly (Mattila et al., 2009); teachers failed to give up their traditional roles in entrepreneurship education (Kbathgate et al., 2013); teacher training did not involve courses to increase understanding of entrepreneurship topics and it has not yet been realised that entrepreneurship education topics must be taught to teachers (Kleppe, 2002); teachers were not aware of entrepreneurship education and failed to adapt to the techniques used in entrepreneurship education (Figueiredo-Nery \& Figueiredo, 2008); there were signs of insecurity among teachers regarding entrepreneurship (Mattila et al., 2009); primary school students had difficulty in expressing themselves in terms of entrepreneurship (Cankar et al., 2013); methodological tools and materials and cooperation with the private sector were inadequate (Žibènienè, 2012); public schools did not contain any practical element for entrepreneurship (Brown, 2012); and finally, the coverage of entrepreneurship in the curricula implemented in teacher education was not satisfactory (Seikkula-Leino et al., 2012).

Entrepreneurial characteristics/competences/skills. In addition, there were study results about entrepreneurial characteristics, skills and competences. For example, according to teachers, students have limited risk-taking attitudes (Akyürek \& Şahin, 2013); "Entrepreneurial Development Coaching" developed teamwork, cooperation and the entrepreneurial mentality of teachers (Gustafsson-Pesonen \& Remes, 2012); entrepreneurship had a positive influence on educators in terms of access to information, cooperation and communication (Chukwurah, 2010); teachers had medium personal cognitive control and innovative behaviours, and they had high entrepreneurial self-efficacy (Pihie et al., 2011b); 
teachers gained self-confidence in the teaching of entrepreneurship (Fischer, 2000); pre-service teachers acquired qualifications such as innovativeness, confidence, professionalism, and leadership (Amos \& Onifade, 2013); pre-service preschool teachers had a high perception of entrepreneurship (Konokman \& Yelken, 2014); those teachers who wanted to be an entrepreneur had more entrepreneurial characteristics (Bakar et al., 2001); and finally, teachers strengthened themselves on the subject of entrepreneurship education (SeikkulaLeino, 2011).

Pertaining to science education. Another finding from the study results was the size of the number of results pertaining to science education among teaching areas. For example, it promoted the employment of science graduates (Adeyemo, 2009); it created an innovative learning domain in science lessons (Koehler, 2013); the importance of entrepreneurship was understood better when it was applied to chemistry lessons (Ezeudu et al., 2013); teachers had a positive approach to the integration of entrepreneurship into science education (Bolaji, 2012); entrepreneurial instructors must evaluate candidates for science-based innovativeness (Armstrong \& Tomes, 2000); science teachers thought that student-centred methods and techniques may be effective (Bacanak, 2013); entrepreneurship education may be implemented in science education (Ugwu et al., 2013); the 'Entrepreneurial scientific thinking' learning model was developed for science education (Buang et al., 2009); and finally, pre-service teachers who are from science-related branches had more positive perceptions in comparison to those from other branches (Amos \& Onifade, 2013).

Entrepreneurship Education Curriculum. The study results showed that entrepreneurship education was included in national curricula in many European countries (Žibėnienè, 2012); entrepreneurial attitude had the widest coverage in third grade textbooks at primary school level (Fakharzadeh, 2011); teachers believed that entrepreneurship must be included in compulsory education (Baranović \& Stibric, 2007); and finally, entrepreneurship in teacher education had been included through a cross-curricular approach (Hamid, 2013; Seikkula-Leino et al., 2012).

Positive indicators. It was seen that some positive results had been 
obtained about entrepreneurship education in the study results. For example, teachers and students believed in the importance of entrepreneurship education (Cheung, 2008); the majority of preservice teachers were amenable to entrepreneurship education (Lepistö \& Ronkko, 2013); teachers participating in training on entrepreneurship found education beneficial (Gardner, 2013); entrepreneurship had a positive influence on teacher training programs with its innovative nature (Chukwurah, 2010); those who had the most positive attitudes were guidance counselors (Hamid, 2013); principals had positive views about entrepreneurship (Deakins et al., 2005) amd finally, teacher trainers made good efforts towards entrepreneurship education (Hannula et al., 2012).

\section{The Distribution of the Studies in Terms of Recommendations}

Suggestions made in the investigated studies were collected under four themes: (1) basic education, (2) teachers and educators, (3) teacher training, (4) curriculum development process.

Basic education. It was seen that there were far more recommendations in the studies examined. These recommendations greatly involved recommendations regarding basic education. The studies falling under this theme generally made recommendations such as developing the entrepreneurial characteristics of children at an early age, making students acquire knowledge, skills and experience about entrepreneurship, incorporating entrepreneurship into basic education curricula, and conducting more entrepreneurship education study on this level. For example, in-service training should be given to teachers on entrepreneurship education for pre-school, primary and middle school education (Bacanak, 2013; Bolaji, 2012; Seikkula-Leino et al., 2010; Torokoff, 2006), more attention should be focused on processes aimed at developing students' entrepreneurial characteristics (Ejinkeonye \& Chukwuone, 2014; Ememe et al., 2013; Nwoye, 2012), students' entrepreneurship knowledge, skills and experience should be increased (Caseiro \& Alberto, 2013; Fagan, 2006), and entrepreneurship education should be included in curricula on all levels (Amos \& Onifade, 2013; Gustafsson-Pesonen \& Remes, 2012).

Teachers and educators. Under this theme, it was seen that recommendations were made for teachers and educators about 
entrepreneurship education. For example, teachers should understand the problems of students regarding entrepreneurial characteristics (Adeyemo, 2009); it should be examined how teachers can produce innovative ideas (Oplatka, 2014); principals should create an appropriate entrepreneurial environment for entrepreneurship in schools (Ememe et al., 2013); the entrepreneurship education practices of teachers should be monitored (Hamid, 2013); teachers should use entrepreneurial activities in every stage of the learning process (Hietanen, 2013); it should be ensured that teachers transfer their entrepreneurial self-efficacy to students (Pihie et al., 2011a); it should be ensured that teachers have positive attitudes towards entrepreneurship education (Torokoff, 2006); teachers' entrepreneurship knowledge, skills and experience should be increased (Fagan, 2006); and finally, teachers' learning needs should be determined regarding entrepreneurship (Seikkula-Leino et al., 2010).

Teacher training. Suggestions as to what should be done in teacher education under this theme were included. For example, entrepreneurship education should be included in teacher training curriculum (Bakar et al., 2001; Baranović \& Stibric, 2007; Fagan, 2006; Gustafsson-Pesonen \& Remes, 2012; Žibènienè, 2012); experimental and conceptual works should be incorporated in entrepreneurship lessons for teacher training (Hannula, 2011; Van Dam et al., 2010); there should be cooperation with business sectors in the educational process in teacher training (Žibėnienè, 2012); different types of participants should be included in entrepreneurship education and its influence should be investigated (Hannula et al., 2012); teacher training programmes should be constructed (Konokman \& Yelken, 2014); and finally, teacher trainers should focus on providing self-efficacy and attitude (Pihie et al., 2011b).

Curriculum development process. Some suggestions on the curriculum under this theme were made. For example, people specialised in entrepreneurship education should take part in the curriculum development process (Hamid, 2013); curricula should be designed by considering the changes in business life and in society (Seikkula-Leino et al., 2012); it was stated that the way in which entrepreneurship should be included in science education should be concentraetd on (Ugwu et al., 2013); and finally, more concrete assessment tools were needed for entrepreneurship 
education (Mattila et al., 2009).

\section{DISCUSSION AND CONCLUSION}

This section mostly focuses on findings regarding needs, aims, results and recommendations. Most of the studies investigated were undertaken in recent years. It can be interpreted that entrepreneurship education is a current topic in teacher education. It has been noted that a large majority of the investigated studies were carried out in EU countries, especially Finland (for example, Lepistö \& Ronkko, 2013; Mattila et al., 2009; Ruskovaara et al., 2010; Seikkula-Leino, 2011). In this sense, it can be said that EU countries stress the importance of entrepreneurship education in terms of teacher education. The following paragraphs discuss each theme separately.

Needs. The reasons behind the investigated studies mostly focus on curriculum, teacher training, economics and unemployment, entrepreneurial characteristics and the importance of teachers. Since entrepreneurship education has recently begun to be covered within the scope of general education, there is no clear information or consensus on the way it must be included in the curricula, the way its content must be created, what kinds of activities must be carried out, what entrepreneurial characteristics must be focused on, and what assessment tools must be used. For example, Cheung (2008) reports that the high school curriculum is inadequate in terms of entrepreneurship education; Kleppe (2002) notes that the primary education curriculum does not contain enough information about entrepreneurship; and Ugwu, La'ah, and Olotu (2013) argue that basic education curricula are inconsistent with labour demand. These researchers show these situations to be reasons for their study. It is not possible to expect teachers to be engaged in practical activities on a subject about which they do not have any knowledge, skills or experience. Firstly, teachers should be provided with or informed of the theoretical content of entrepreneurship and entrepreneurship education, the importance of entrepreneurship education for students' entrepreneurial characteristics, and sample in-class practices. However, today's teachers are expected to conduct educational activities about those concepts which are included in curricula, even though they have not confronted such concepts before. This brings about many problems for teachers, and 
has increased the number of reasons associated with teachers and pre-service teachers that have motivated researchers to undertake studies. For example, Van Dam (2010) reports that not enough studies have been conducted on teachers with regard to entrepreneurship education in the school environment; Hannula et al. (2012) note that entrepreneurship education has not been completely generalised in teacher training; Adeyemo (2009) argues that teachers must learn basic entrepreneurship education concepts; Hietanen (2013), and Correia, Wang, and Baran (2010) say that pre-service teachers must have entrepreneurial characteristics. These researchers show these situations to be reasons for their studies.

Aims. The studies largely aim to investigate the views, perceptions and attitudes of students, teachers or other educators concerning entrepreneurship. This may be due to the need to determine what teachers, teacher trainers or others think about inclusion of up-todate concepts such as entrepreneurship or entrepreneurship education in the curricula. For example, Mattila, Rytkölä, and Ruskovaara (2009) aim to examine teachers' views about entrepreneurship education. Amos and Onifade (2013) intend to examine the views of pre-service teachers concerning the necessity of entrepreneurship education in teacher education. Further, Chukwurah (2010) aims to examine the views of instructors about entrepreneurship in teacher training, while Pistorius (2011) aims to examine the views of primary school economic management sciences teachers about entrepreneurship. In this sense, it is important to determine the views of educators about the way entrepreneurship education must be incorporated in curricula. As a matter of fact, Baranović and Stibric (2007) also aim to determine the views of teachers about the way the skills or competencies of entrepreneurship are to be integrated into compulsory education. Thus, it can be said that these are all studies aiming to examine the views, perceptions and attitudes of all educational personnel from primary education level to university level about entrepreneurship education. The purpose of such studies may be to answer the following questions: Does entrepreneurship education have to be included in curricula? How does it have to be included in curricula?

Most studies aim to discuss science education, possibly because the main qualifications to be given toindividuals throughentrepreneurship education are parallel to those given to individuals though science 
education. It is acknowledged that experiential learning is more effective in developing entrepreneurial characteristics and attitudes in comparison to traditional methods such as traditional lectures (European Commission, 2008). Pedagogy implemented in science education is also experiential, which indicates another parallel between entrepreneurship education and science education. On the other hand, it is reported that active learning and the constructivist approach must be used in entrepreneurship education (Koopman, Hammer, \& Hakkert, 2013). It is known that the fundamental philosophy of science education involves active learning, and so the constructivist approach is adopted in preparing curricula. This also demonstrates a parallelism between entrepreneurship education and science education. Certain studies promote entrepreneurship in science education and aim to ensure a better understanding of entrepreneurship education (Adeyemo, 2009; Buang, Halim, Meerah, \& Osman, 2007). On the other hand, it is reported that the entrepreneurial mentality of students is developed through STEM education, which is closely associated with science education (Jin, Li Yang, \& Son, 2014). There seems to be a lot of studies emphasizing the importance of integrating entrepreneurship into science education (Bolaji, 2012; Buang et al., 2009; Ezeudu et al., 2013; Ugwu et al., 2013).

Since the literature does not contain enough sources presenting sample in-class entrepreneurial activities that may guide educators, there are now attempts to investigate what kinds of activities teachers carry out and why they cannot implement entrepreneurial activities. There are also studies on the influence of the activities on students (Brown, 2012; Cheung, 2008; Figueiredo-Nery \& Figueiredo, 2008; Oplatka, 2014). As can be seen, these researchers are interested in what kinds of in-class activities teachers carry out within the scope of entrepreneurship education. Studies of this sort may continue to be conducted until entrepreneurship education activities are standardised.

It is also important to search the ideal content of entrepreneurship education as well as the manner in which it should be handled. In this regard, theoretical and compilation studies are important to ensure a better understanding of entrepreneurship education. As a matter of fact, the literature contains studies aiming to inform teachers about entrepreneurship education (Adeyemo, 2009; Borase, 2014; 
Caseiro \& Alberto, 2013; Fagan, 2006). As it is understood, the education literature contains a lot of studies aiming to enhance the understanding of entrepreneurship education, which is a current issue especially in teacher training. Studies on the way entrepreneurship education is addressed in the general education curricula are also important. Studies of this sort may guide both teachers and those experts who develop curricula (Hannula, 2011; Ruskovaara et al., 2010). Considering these studies, it can be said that entrepreneurship education must be included in curricula based on a fundamental philosophy, but it should not be treated as just an ordinary topic covered in curricula.

Results. Numerous study findings highlighting the importance of entrepreneurship in teacher education are available. It can be said that much emphasis has been placed on the methods, techniques, models or strategies used in entrepreneurship education in this sense. This emphasis can be attributed to the effort to clarify how to best teach entrepreneurship, which is a new concept in education. For example, it has been reported that teachers mostly use group work, writing a story, discussion, diaries and school visits during the entrepreneurship training process (Ruskovaara et al., 2010). These studies show that teachers try to employ processes in which students can interact with one another or others in the process of entrepreneurship education. Furthermore, by making students keep a journal and communicate with different people, teachers make an effort to improve their communication skills. In addition, out-of-school visits may be organised. It is understood that cooperation with private and public sectors is important in the process of entrepreneurship education. In this regard, teachers and school administrators must have a good network of communication with out-of-school circles (e.g., different professions, factories, scientific centres, zoos). As a matter of fact, it has been reported that school administrators play an important role in entrepreneurship education practices (Deakins et al., 2005; Ememe et al., 2013), and teachers should communicate with the local community (Baranović \& Stibric, 2007). In addition, it is stated that teachers should spend extra time outside the school in the process of entrepreneurship education (Oplatka, 2014) and make use of extracurricular activities (Baranović \& Stibric, 2007). Thus, it seems that private schools place more emphasis on out-of-school activities in the entrepreneurship training process (Brown, 2012). This may be because private schools have better conditions and a more flexible 
structure. The approaches adopted by teachers in entrepreneurship education are also important. In general, problem-based approaches in which students are active are preferred. As a matter of fact, the results of the studies demonstrate that teachers use problem-based active learning approaches (Ruskovaara et al., 2010).

On the other hand, the results of the studies about entrepreneurship education also point to many deficiencies with regard to educators, learning environments, teaching processes and materials. These results are quite normal because neither educators nor the current learning environments have adequate backgrounds/infrastructures to put entrepreneurship into practice (Figueiredo-Nery \& Figueiredo, 2008; Kbathgate et al., 2013; Mattila et al., 2009). Moreover, with regard to the learning environment, the study results demonstrate that principals limit themselves in terms of implementing entrepreneurial activities (Deakins et al., 2005); that the physical condition of schools is not adequate for entrepreneurship education (Figueiredo-Nery \& Figueiredo, 2008); that appropriate technological and laboratory environments must be created for entrepreneurship (Ejinkeonye \& Chukwuone, 2014); that methodological tools and materials and cooperation with the private sector are inadequate (Žibènienè, 2012); and finally, that public schools do not contain any practical elements or support for such teaching (Brown, 2012).

On the other hand, it has been observed that entrepreneurship education has a positive influence on pre-service teachers. For instance, it was seen that pre-service teachers acquire qualifications such as innovativeness, confidence, profession and leadership, thanks to entrepreneurship education (Amos \& Onifade, 2013). It has also been stated that pre-service preschool teachers have a high perception of entrepreneurship (Konokman \& Yelken, 2014). As for music education, pre-service teachers strengthen their musical competence through entrepreneurship education (Hietanen, 2013).

The results of studies conducted in the field of science education mostly concern the integration of entrepreneurship education into science education. It is noteworthy that results have been obtained with regard to this aspect. For example, it has been reported that entrepreneurship education provides an innovative learning domain for science lessons (Koehler, 2013). Similarly, it has been highlighted that entrepreneurship education may be implemented in science education (Ugwu et al., 2013). Besides, it has been emphasised 
that the importance of entrepreneurship is understood better when it is applied to chemistry lessons (Ezeudu et al., 2013). Moreover, there are positive results about teachers' views. Bolaji (2012) says that science teachers have a positive approach to the integration of entrepreneurship into science education. Moreover, Bacanak (2013) argues that science teachers think that student-centred methods and techniques may be effective in entrepreneurship education within the scope of science lessons. Amos and Onifade (2013) conclude that pre-service teachers from science-related branches have more positive perceptions in comparison to those from other branches. This may imply that bigger steps have been taken for the inclusion of entrepreneurship education in science education in comparison to other branches. For example, Buang et al. (2009) have developed the five-step "Entrepreneurial Scientific Thinking" learning model for science education. Besides these positive aspects, there are also certain deficiencies. Nwoye (2012) concludes that high school physics students have low entrepreneurial characteristics, and that the physics curriculum lacks the resources for the introduction of entrepreneurial characteristics. In addition, science teachers are not sufficiently knowledgeable of entrepreneurship education (Bacanak, 2013). There are also research results about the degree to which entrepreneurship education is covered in general education curricula as well as the way it must be covered. Most teachers think that entrepreneurship must be part of compulsory education (Baranović \& Stibric, 2007). One of the topics most subject to discussion is whether entrepreneurship education must be treated as an individual topic in curricula or whether it should be handled through a cross-curricular approach. The researchers have obtained results suggesting that it must be handled through a cross-curricular approach (Hamid, 2013).

\section{RECOMMENDATIONS}

The recommendations put forward in the studies reviewed mostly concern a basic level of education. Many of these studies state that in-service training should be given to teachers at the basic education level with regard to entrepreneurship education. Many of these studies suggest that in-service training should be provided to teachers at basic education levels regarding entrepreneurship education (Akyürek \& Şahin, 2013; Nwoye, 2012; Seikkula-Leino et al., 2010; Torokoff, 2006). In this way, it is to be emphasised that teachers must gain 
knowledge, skills and experience in entrepreneurship education. In this way, the importance of theoretical content and practical activities for entrepreneurship education in basic education curricula is highlighted. For example, some researchers clearly recommend the inclusion of entrepreneurship education in all curricula (Amos \& Onifade, 2013; Gustafsson-Pesonen \& Remes, 2012). Aside from this point, it is also recognised that more attention should be focused on processes aimed at developing students' entrepreneurial characteristics (Ememe et al., 2013; Ejinkeonye \& Chukwuone, 2014; Nwoye, 2012). Moreover, it is said that entrepreneurship education should be included in school curricula (Cheung, 2008; Gustafsson-Pesonen \& Remes, 2012); in other words, researchers are insistent on bringing entrepreneurship education down to the basic education level. Another prominent issue on the basic education level is the cooperation of schools with the business world (Cankar et al., 2013; Deakins et al., 2005; Orji, 2014). In considering these recommendations, it can be said that there should be close interaction with the business world in entrepreneurship education. This must start from the basic level of education.

A lot of recommendations are put forward with regard to teachers and educators. Indeed, attention should be focused on teachers and educators in the first place so that entrepreneurship education is improved and promoted (Fagan, 2006; Hamid, 2013; Oplatka, 2014; Orji, 2014; Torokoff, 2006). Moreover, as has been ascertained, one of the important dimensions of entrepreneurship education is preservice training. In this regard, a lot of recommendations are being put forward in the reviewed studies pertaining to pre-service teacher training. Many researchers state that entrepreneurship education should be included in teacher education curricula (Bakar, et al., 2001; Baranović \& Stibric, 2007; Fagan, 2006; Gustafsson-Pesonen \& Remes, 2012; Žibènienè, 2012).

Some other recommendations can be listed as follows: there should be cooperation with business sectors in the educational process in teacher training (Žibènienè, 2012); different types of participants should be included in entrepreneurship education and their influence should be investigated with regard to entrepreneurship (Hannula et al., 2012); and finally, experimental and conceptual works should be incorporated in entrepreneurship lessons (Hannula, 2011; Van Dam et al., 2010). Considering the difficulties experienced by today's teachers along with these recommendations, it should 
be understood that pre-service training is of great importance. Presumably, because of this view, it is considered highly important that pre-service teachers become acquainted with entrepreneurship education during pre-service training. Accordingly, it can be said that teacher education curricula should be revised, and that current concepts should be introduced to pre-service teachers. For example, Konokman and Yelken (2014) argue that teacher training programs should be reconstructed so that entrepreneurship education is completely covered in existing programmes.

\section{FUTURE RESEARCH RECOMMENDATIONS}

All in all, it can be said that teachers, teacher trainers and pre-service teachers are quite pessimistic about entrepreneurship education while still considering entrepreneurship education to be beneficial. Thus, attempts are made to generalise entrepreneurship education, especially at primary and secondary education levels. In this sense, attention is focused upon teachers' knowledge, skills and experience regarding entrepreneurship education. In addition, researchers have emphasised the importance of the inclusion of entrepreneurship education in pre-service teacher training. There are also positive results about the incorporation of entrepreneurship education in general education courses or different teaching courses. As for the teaching domain (branch), most studies have been conducted in the field of science education. Moreover, great attention is focused on the way entrepreneurship education has been covered in curricula or the way it is to be incorporated in them. Many studies aim to determine the current situation and employ the survey method. There are very few studies employing experimental designs and no research currently employs the mixed design.

\section{REFERENCES}

Abiogu, G. C. (2011, October). Entrepreneurship education: A veritable means of reconstructing tertiary institutions in Nigeria. The 29 Thannual Conference of Philosophy of Education Association Of Nigeria (PEAN), Lagos State University, Ojo - Lagos State. 
Adeyemo, S. A. (2009). Understanding and acquisition of entrepreneurial skills: A pedagogical re-orientation for classroom teacher in science education. Journal of Turkish Science Education, 6(3), 57-65.

Akyürek, Ç., \& Şahin, Ç. (2013). Evaluation of elementary teachers' entrepreneurship skills. Ekev Akademi Dergisi, 17(57), 5168.

Ali, J., Lim, H. E., Ismail, R., Abdul Rahim, F., Md Isa, F., \& Ismail, I. A. (2014). The effectiveness of finishing school programmes from the perspectives of graduates and employers. Malaysian Journal of Learning and Instruction, $11,147-170$.

Altan, M. Z. (2015). Entrepreneurial teaching \& entrepreneurial teachers. Journal for Educators, Teachers and Trainers, 6(2), 35-50.

Amos, A., \& Onifade, C. A. (2013). The perception of students on the need for entrepreneurship education in teacher education programme. Global Journal of Human-Social Science Research, 13(3), 75-80.

Armstrong,P., \& Tomes,A.(2000). Entrepreneurship in Science: Case studies from liquid crystal application. Prometheus, 18(2), 133-147. doi:10.1080/713692057

Arpac1, İ. (2015). Student assessment of teaching effectiveness in entrepreneurship course at the faculty of education. Sakarya Üniversitesi Ĕ̈itim Fakültesi Dergisi, 30, 147-163.

Ay, T. S., \& Acar, S. (2016). Views of classroom teachers about the acquisition of entrepreneurial skills. Electronic Journal of Social Sciences, 15(28), 960-976.

Bacanak, A. (2013). Teachers' views about science and technology lesson effects on the development of students' entrepreneurship skills. Educational Sciences: Theory \& Practice, 13(1), 622-629.

Bakar, A., Pihie, L., Akmaliah, Z., Konting, M. M., \& Angking, G. K. (2001). The perceived entrepreneurial characteristics of Malaysian living skill teachers: Implication for teacher preparation programme. Pertanika Journal of Social Sciences \& Humanities, 9(2), 123-129.

Baranović, M., \& Stibric, M. (2007, July). The development of entrepreneurial competence in Croatian compulsory 
education. Meeting in related to Key competencies skills for life. London, Velika Britanija.

Bolaji, O. A. (2012). Intergrating enterpreneurship education into science education: Science teachers perspectives. Journal of Science, Technology, Mathematics and Education, 8(3), 181-187.

Borase, C. (2014). The Entrepreneurial teacher. Online International Interdisciplinary Research Journal, 4(5), 231-234.

Brown, M. H. M. (2012). Entreprneur education assessment in secondary schools. A research report. University of Pretoria. The Gordon Enstitute of Business Science, South Africa.

Buang, N. A., Halim, L., Meerah, T. S. M., \& Osman, K. (2007). Development of entrepreneurial science thinking model for malaysian science and technology education. Seminar Pendidikan Kejuruteraan dan Alam Bina. Malaysia.

Buang, N. A., Halim, L., \& Meerah, T. S. M. (2009). Understanding the thinking of scientists entrepreneurs: Implications for science education in Malaysia. Journal of Turkish Science Education, 6(2), 3-11.

Borasi, R., \& Finnegan, K. (2010). Entrepreneurial attitudes and behaviors that can help prepare successful change-agents in education. New Educator, 6(1), 1-29.

Bygrave, W. D. \& Hofer, C. W. (1991). Theorizing about entrepreneurship. Entrepreneurship Theory and Practice, $16,13-22$.

Cankar, F., Deutsch, T., Zupan, B., \& Cankar, S. S. (2013). Schools and promotion of innovation. Croatian Journal of Education, 15(2), 179-211.

Caseiro, N., \& Alberto, D. (2013, June). Teaching entrepreneurship at non-business schools: A reflexion. The Conference on Enabling Teachers for Entrepreneurship Education (ENTENP2013), Potugal.

Cheung, C. K. (2008). Practicing entrepreneurship education for secondary pupils through the operation new year stall in Hong Kong. Asia-Pacific Education Researcher, 17(1), 1531. doi: 10.3860/taper.v17i1.347

Chou, C. M., Shen, C. H., Hsiao, H. C., Chang, H. T., Lee, W. H., Chen, S. C., Chen, C. P., \& Chang, J. C. (2011, April) The influencing factors of student teachers' entrepreneurial 
learning behavior. 2011 Fourth International Joint Conference on Computational Sciences and Optimization. Yunnan. Hong Kong.

Chukwurah, C. C. (2010). Globalisation, entrepreneurship and teacher education in Nigeria: challenging roles of vocational educators. International Journal of Management in Education, 4(4), 369-375. doi:10.1504/ijmie.2010.035605

Correia, A. P., Wang, W., \& Baran, E. (2010, March). Bringing entrepreneurship into graduate teacher education. Society for Information Technology \& Teacher Education International Conference. San Diego, CA.

Çalık, M., Ayas, A., \& Ebenezer, J. V. (2005). A review of solution chemistry studies: insights into students' conceptions. Journal of Science Education and Technology, 14(1), 2950. doi:10.1007/s10956-005-2732-3

Çelik, E. (2010). The effect of problem based learning approach in science education on students? academic achievement, attitude, academic risk taking level and retention of knowledge (Unpublished master's thesis). Institute of Educational Sciences, Gazi University, Ankara.

Çelik, H., Gürpınar., C., Başer., N., \& Erdoğan. S. (2015). Opinions of science teacher towards of students' creative thinking and entrepreneurship skills. The Journal of International Education Science, 2(4), 277-307.

Deakins, D., Glancey, K., Menter, I., \& Wyper, J. (2005). Enterprise education: The role of head teachers. The International Entrepreneurship and Management Journal, 1(2), 241-263. doi:10.1007/s11365-005-1131-9

Deveci, İ. (2016a). Science-based entrepreneur project development process for pre-service science teachers: Difficulties faced. Research In Teacher Education, 6(1), 30-35.

Deveci,İ.(2016b).Perceptions and competence ofTurkish pre-service science teachers with regard to entrepreneurship. Australian Journal of Teacher Education, 41(5), 153-170.

Deveci, İ., \& Çepni, S. (2015a). Development of entrepreneurship scale towards student teachers: a validity and reliability study. International Journal of Human Sciences, 12(2), 92112.

Deveci, İ., \& Çepni, S. (2015b). Examining science teacher candidates' entrepreneurial characteristics according to some variables. International Online Journal of Educational 
Sciences, 7(3), 135-149.

Deveci, İ., \& Seikkula-Leino, J. (2016). Finnish science teacher educators' opinions about the implementation process related to entrepreneurship education. Electronic Journal of Science Education, 20(4), 1-20.

Deveci, İ., Zengin, M. N., \& Çepni, S. (2015). Development and evaluation of science based enterprising training module.Journal of Educational Sciences \& Practices, 14(27), 59-80.

Deveci, İ., \& Seikkula-Leino, J. (2015). Entrepreneurship in Finnish teacher training. The International Journal of Research in Teacher Education, 6(3), 24-39.

Dijk, V. T., \& Mensch, C. (2015). Entrepreneurship education in swedish compulsory schools: the perception and implementation from an educator's viewpoint (Master's degree), Department of Business Administration, LUP Student Papers, Lund University Libraries

Ejinkeonye, U. B., \& Chukwuone, C. A. (2014). Strategies for fostering entrepreneurship education in home economics at secondary school level in anambra state Nigeria. Journal of Education and Practice, 5(19), 51-55.

Ememe, O.N.,Ezeh S.C., \& Ekemezie, C.A.(2013). The role of headteacher in the development of entrepreneurship education in primary schools. Academic Research International, 4(1), 242-249.

European Commission, (2004). Helping to create an entrepreneurial culture A guide on good practices in promoting entrepreneurial attitudes and skills through education. Unit B.1: Entrepreneurship (SC27 3/4)Directorate-General for Enterprise, B-1049 Brussels.

European Commission, (2006). Entrepreneurship education in Europe. Fostering entrepreneurial mindsets through education and learning. Retrieved from http://ec.europa.eu/ enterprise/policies/sme/files/supportmeasures/trainingeducation/ doc/osloagendafinalen.pdf

European Commission. (2008). Entrepreneurship in higher education, especially within non-business studies: final report of the expert group. Brussels, Belgium.

European Commission. ( 2010). Europe 2020. A European strategy 
for smart, sustainable and inclusive growth. COM (2010) 2020. Communication from the Commission. Retrieved from http://ec.europa. eu/eu2020/pdf/COMPLET\%20 EN\%20BARROSO\%20\%20\%20007\%20-\%20Europe\%20 $2020 \% 20 \% 20 \mathrm{EN} \% 20$ ve sion.pdf at 18.07 .2015

European Commission. (2011). Entrepreneurship education: Enabling teachers as a critical success factor. A report on teacher Education and training to prepare teachers for the challenge of entrepreneurship education. Final Report, Entrepreneurship Unit, Bruxelles.

European Commission. (2013). Entrepreneurship education: A guide for educators. Entrepreneurship and Social Economy Unit. European Union, Bruxelles.

European Training Foundation, (2010). A pilot action on entrepreneurship education: High level reflection panel. Working Paper presented at the Fifth Cluster Meeting. Zagreb, Croatia, Retrieved from http://www. etf.europa.eu/ pubmgmt.nsf/(getAttachment)/F14FA189 FEB04301C12577520031F749/\$File/NO TE 86WCP3.pdf at 12.12 .2011

Ezeudu, F. O., Ofoegbu, T. O., \& Anyaegbunnam, N. J. (2013). Restructuring STM (science, technology, and mathematics) education for entrepreneurship. US-China Education Review A, 3(1), 27-32.

Fagan, C. (2006). Three Es for teachers: Economics, enterprise and entrepreneurship. Teacher Development, 10(3), 275-291. doi:10.1080/1366453060092 1767

Fakharzadeh, A. (2011). Development of entrepreneurial attitude in Iranian elementary literature textbooks. Journal of Entrepreneurship Education, 15, 49-62.

Figueiredo-Nery, M. A. N., \& Figueiredo, P. N. (2008). Forming entrepreneurial mindsets? preliminary evidence of teaching practices from primary schools in a developing area in South America. Journal of Technology Management \& Innovation, 3(2), 1-17.

Fischer, T. J. (2000). An assessment of an economics and entrepreneurship curriculum for middle level students (Unpublished doctoral dissertation). University of Nebraska, Faculty of The Graduate College, Lincoln.

Fraenkel, J. R., \& Wallen, N. E. (2006). How to design and evaluate 
research in education. Sixth Edition. New York: McGrawHill.

Gardner, L. L. (2013). Teaching teachers about supply chain management to influence students' career and education choices. Decision Sciences Journal of Innovative Education, $\quad 11(2), \quad 185-192 . \quad$ doi:10.1111/j.15404609.2013.00372.x

GHK (2011). Order 129: Mapping of teachers' preparation for entrepreneurship education. Framework Contract NoEAC19/06,DG Education and Culture, Final Report. Retrieved from http://www.ab. gov.tr/files/ardb/evt/1_ avrupa_birligi/1_9_politikalar/ 1_9_4_egitim_politikasi / mapping_en.pdf

Gibb, A. (2005). The future of entrepreneurship education Determining the basis for coherent policy and practice? In P. Kyrö, \& C. Carrier (Eds.), The dynamics of learning entrepreneurship in a cross-cultural university context (44-67). Entrepreneurship Education Series 2/2005. Hämeenlinna: University of Tampere, Research Centre for Vocational and Professional Education.

Given, L. M. (2008). The Sage encyclopedia of qualitative research methods (Ed.). Sage Publications. California: SAGE Publications. Inc. ThousandOaks.

Gustafsson-Pesonen, A., \& Remes, L. (2012). Evaluation of entrepreneurial development coaching: Changing the Teachers' thinking and action on entrepreneurship. Annals of Innovation \& Entrepreneurship, 3. doi:10.3402/aie. v3i0.17211

Hamid, M. A. (2013). Entrepreneurship education: The implementation in Year 1 primary school curriculum in Malaysia. A case study of one district in East Peninsular Malaysia (Unpublished doctoral dissertation). The University of York, England. Reterieved from http://etheses.whiterose. ac.uk/6141/1/Final\%20-\%20for\%20hard\%20cover.pdf

Hannula, H. (2011, October). Entrepreneurship education in the strategies and curricula of finnish vocational teacher education. Contemporary Views on Business Developing Business Excellence. Hämeenlinna, Finland.

Hannula, H., Ruskovaara, E., Seikkula-Leino, J., \& Tiikkala, A. (2012, June). Evaluating finnish teacher educators as entrepreneurship educators. Paper presented in the 8th 
International Conference on Evaluation for Practice, Improvement by Evaluation. A Conference for Experts of Education, Human Services and Policy. Pori, Finland.

Haara, F. O., \& Jenssen, E. S. (2016). Pedagogical entrepreneurship in teacher education-what and why? Icelandic Journal of Education, 25(2), 183-196.

Heilbrunn, S. (2010). Advancing entrepreneurship in an elementary school: a case study. International Education Studies, 3(2), 174-184. doi: 10.5539/ies.v3n2p174

Hietanen, L. (2013, June) Entrepreneurial way of acting as a method in student teachers' compulsory music course. Proceedings Book for the Conference on Enabling Teachers for Entrepreneurship Education. Potugal.

Hsiao, A. (2010, June). Nanomaterials in Newfoundland: Designing a Lab Kit for Grades 9-12 to bridge the gap between science and engineering. The Canadian Engineering Education Association. Canadian.

Ireland, R. D., Hitt, M. A., \& Sirmon, D. G. (2003). A model of strategic entrepreneurship: the construct and its dimensions. Journal of Management, 29(6), 963-989. doi: 10.1016/ s0149-2063(03)00086-2

Jin, K., Li, H., Yang, L., \& Song, Q. (2014, March). Introducing entrepreneurship thinking into STEM curriculum through hands-on projects. International Conferences New Perspectives in Science Education. Florence, Italy.

Kbathgate, I., Mostert, A., \& Sandland, S. (2013). Learning styles and team roles - Lessons for Gregorc based teams for effective enterprise development. Journal for Educators, Teachers and Trainers, 4(2), 95 - 105.

Kleppe, J. A. (2002). Teaching invention, innovation, and entrepreneurship to Northern Nevada high school science and math teachers. Antennas and Propagation Magazine IEEE, 44(5), 115-119.

Knight, F. H. (1921). Risk, uncertainty and profit. 2e. London: Houghton-Mifflin Co.

Koçak, B., Polat, S., Çermik, F., Meral, E., \& Boztaş, M. (2015). İlköğretim sosyal bilgiler ders kitaplarının girişimcilik kazanımı açısından öğretmen görüşlerine göre değerlendirilmesi. EKEV Akademi Dergisi, 62(62), 455470.

Koehler, J. L (2013). Entrepreneurial teaching in creating third 
spaces for experiential learning: A case study of two science teachers in low-income settings (Unpublished doctoral dissertation). The Graduate College of the University of Illinois at Urbana-Champaign, Urbana, Illinois.

Konokman, G. Y., \& Yelken, T. Y. (2014). Investigation of preschool teacher candidates' attitudes towards learning and their entrepreneurship levels. International Online Journal of Educational Sciences, 6 (3), 648-665

Koopman, R., Hammer, M., \& Hakkert, A. (2013, June). Teaching teachers in effectual entrepreneurship. Paper presented in the 2nd Effectuation Conference. Lyon, France.

Kuratko, D. F., \& Hodgetts, R. M. (2004). Entrepreneurship: Theory, process, practice. Mason, $\mathrm{OH}$ : South-Western Publishers.

Kurnaz, M. A., \& Çalık, M. (2009). A thematic review of 'energy' teaching studies: focuses, needs, methods, general knowledge claims and implications. Energy Education Science and Technology Part B: Social and Educational Studies, 1(1), 1-26.

Lepistö, J., \& Ronkko, M. L. (2013). Teacher students as future entrepreneurship educators and learning facilitators. Education +Training, 55(7), 641-653. doi:10.1108/ET-052012-0055

Mars, M., \& Rios-Aguilar, C. (2010). Entrepreneurship (re)defined: Significance and implications for the scholarship of higher education. Higher Education, 59(4), 441-460. doi:10.1007/ s10734-009-9258-1

Mattila, M., Rytkölä, T., \& Ruskovaara,E.(2009, February). Creating a picture of a teacher as an entrepreneurship educator. Paper presented in the EFMD Conference. Barcelona.

Minniti, M., \& Lévesque, M. (2010). Entrepreneurial types and economic growth. Journal of Business Venturing, 25(3), 305-314. doi:10.1016/j.jbusvent.2008.10.002

Nwoye, A. N. (2012) Assessment of resources and the level of entrepreneurial skills acquired by secondary school physics students in anambra state (Unpublished master's thesis) presented to the Department of Science Education, Faculty of Education, Nnamdi Azikiwe University, Awka.

Oplatka, I. (2014). Understanding teacher entrepreneurship in the globalized society: Some lessons from self-starter Israeli school teachers in road safety education. Journal of Enterprising Communities: People and Places in the Global 
Economy, 8(1), 20-33. Doi: 10.1108/JEC-06-2013-0016

Orji, N. S. (2014). Teachers' perception of the trade/entrepreneurship of the new senior secondary education curricula. Journal of Education and Practice, 5(6), 213-219.

Pan, V. L., \& Akay, C. (2015). Examining teacher candidates' entrepreneurship levels in terms of various variables. NWSA: Education Sciences, 9(6), 125-138.

Peltonen, K. (2015). How can teachers' entrepreneurial competences be developed? A collaborative learning perspective. Education + Training, 57(5), 492-511.

Pihie, Z. A. L., \& Bagheri, A. (2011a). Teachers' and students' entrepreneurial self-efficacy: implication for effective teaching practices. Procedia-Social and Behavioral Sciences, 29, 1071-1080. doi:10.1016/j.sbspro.2011.11.340

Pihie, Z. A. L., \& Bagheri, A. (2011b). Are teachers qualified to teach entrepreneurship? analysis of entrepreneurial attitude and self efficacy. Journal of Applied Science, 11(18), 33083314. doi:10.3923/jas.2011.3308.3314

Pistorius, Z. (2011). Entrepreneurship competence of economic management science teachers in the kenneth kaunda district (Master's thesis), Business Administration at the NorthWest University, Potchefstroom Campus, South Africa.

Remes, L. (2003). Yrittäjyyskasvatuksen kolme diskurssia. Jyväskylän yliopisto, Jyväskylä: Jyväskylä University Printing House.

Rönkkö, M. L., \& Lepistö, J. (2015). Finnish student teachers' critical conceptions of entrepreneurship education. Journal of Enterprising Communities: People and Places in the Global Economy, 9(1), 61-75.

Ruskovaara, E., \& Pihkala, T. (2013). Teachers implementing entrepreneurship education: Classroom practices. Education + Training, 55(2), 204-216.

Ruskovaara, E., \& Pihkala, T. (2015). Entrepreneurship education in schools: Empirical evidence on the teacher's role. The Journal of Educational Research, 108(3), 236-249.

Ruskovaara, E., Pihkala, T., Rytkölä, T., \& Seikkula-Leino, J. (2010, August). Studying teachers' teaching methods and working approaches in entrepreneurship education. In Proceedings of the ESU Conference. Tartu, Estonia.

Ruskovaara, E., Pihkala, T., Seikkula-Leino, J., \& Järvinen, M. R. 
(2015). Broadening the resource base for entrepreneurship education through teachers' networking activities. Teaching and Teacher Education, 47, 62-70.

Schumpeter, J. A. (1934). The theory of economic development. Cambridge. MA: Harvard University Press.

Seikkula-Leino, J. (2011). The implementation of entrepreneurship education through curriculum reform in Finnish comprehensive schools. Journal of Curriculum Studies, 43(1), 69-85. doi:10.1080 /00220270903544685

Seikkula-Leino, J., Ruskovaara, E., Hannula, H., \& Saarivirta, T. (2012). Facing the changing demands of Europe: Integrating entrepreneurship education in Finnish teacher training curricula. European Educational Research Journal, 11(3), 382-399. doi:10.2304/eerj.2012.11.3.382

Seikkula-Leino, J., Ruskovaara, E., Ikavalko, M., Mattila, J., \& Rytkola, T. (2010). Promoting entrepreneurship education: The role of the teacher? Education+Training, 52(2), 117127. doi: 10.1108/00400911011027716

Seikkula-Leino, J., Satuvuori, T., Ruskovaara, E., \& Hannula, H. (2015). How do Finnish teacher educators implement entrepreneurship education? Education+Training, 57(4), 392-404. doi: 10.1108/et-03-2013-0029

Shane,S.,\& Venkataraman,S.(2000).Thepromiseofentrepreneurship as a field of research. Academy of Management Review, 25, 217-226.

Silva, M.C.V. (2013, June). Teachers training and entrepreneurship: Challenges in supervisors work. Proceedings Book for the Conference on Enabling Teachers for Entrepreneurship Education (ENTENP2013), Potugal.

Sipon, M., Pihie, Z. A. L., Rahman, F. A., \& Manaf, U. K. A. (2015). Teacher's entrepreneurial pedagogical content knowledge roles in human resource development. International Journal of Management and Applied Research, 2(1), 35-44.

Snow, M.H. (2012). Music education and entrepreneurship: postsecondary music teacher education and value creation for individuals and communities (Unpublished doctoral degree of Musical Arts), University of New Hampshire, New Hampshire.

Suryanti, H. H. S. (2013). The problem based learning (PBL)-based entrepreneurship learning model development to improve 
the life skills of the teacher training students in private universities throughout Solo Raya. Dewantara. International Journal of Education, 1(1), 1-15.

The Ministry of Education, (2017). Science Curriculum (Primary and Middle Schools 3, 4, 5, 6, 7 and 8 grades). Ankara: Head Council of Education And Morality.

Torokoff, M. (2006). Opportunities for schools to develop entrepreneurship education: the example of Estonia. Working Papers in Economics at School of Economics and Business Administration of Tallinn University of Technology, 153, 8196.

Ugwu, A.I., La'ah, E., \& Olotu, A. (2013). Entrepreneurship; performance indicator for innovative/skill acquisition: imperative to science and technology education (STE). World Conference on Science and Technology Education, 29 September - 3 October, Sarawak, Borneo, Malaysia.

Ünal, S., Çalik, M., Ayas, A., \& Coll, R. K. (2006). A review of chemical bounding studies: needs, aims, methods of exploring students' conceptions, general knowledge claims and students' alternative conceptions. Research in Science \& Technological Education, 24(2), 141-172. doi:10.1080/02635140600811536

Van Dam, K., Schipper, M., \& Runhaar, P. (2010). Developing a competency-based framework for teachers' entrepreneurial behaviour. Teaching and Teacher Education, 26(4), 965971. doi: 10.1016/j.tate.2009.10.038

Zalan, T., \& Lewis, G. (2010). Entrepreneurs: Drivers of economic change. Social Science Research Network, 11. Retrieved fromhttps://repository.tudelft.nl/islandora/ object uuid:1a751ea7-557c-4fb0

Žibènienè, G. (2012). The entrepreneurial teacher continuing training: 1mportant aspects and tendencies in Europe. Social Work, 11(2), 379-390. 